\title{
Assessing exposure to cosmic radiation aboard aircraft: the SIEVERT system
}

\author{
J.F. BOTTOLLIER-DEPOIS ${ }^{1}$, A. BIAU ${ }^{1}$, P. BLANCHARD ${ }^{2}$, I. CLAIRAND $^{1}$,

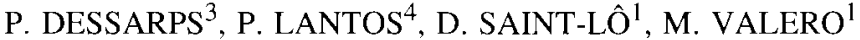

(Manuscript received 26 November 2002, accepted 14 April 2003)

ABSTRACT The study of naturally-occurring radiation and its associated risk is one of the preoccupations of bodies responsible for radiation protection. Cosmic particle flux is significantly higher on board aircraft that at ground level. Furthermore, its intensity depends on solar activity and eruptions. Due to their professional activity, flight crews and frequent flyers may receive an annual dose of some millisieverts. This is why the European directive adopted in 1996 requires the aircraft operators to assess the dose and to inform their flight crews about the risk. The effective dose is to be estimated using various experimental and calculation means. In France, the computerized system for flight assessment of exposure to cosmic radiation in air transport (SIEVERT) is delivered to airlines for assisting them in the application of the European directive. This dose assessment tool was developed by the French General Directorate of Civil Aviation (DGAC) and partners: the Institute for Radiation Protection and Nuclear Safety (IRSN), the Paris Observatory and the French Institute for Polar Research - Paul-Emile Victor (IPEV). This professional service is available on an Internet server accessible to companies with a public section. The system provides doses that consider the routes llown by aircraft. Various results obtained are presented.

RÉSUMÉ Évaluation de l'exposition au rayonnement cosmique à bord des avions : le système SIEVERT.

L'étude des rayonnements d'origine naturelle et le risque associé sont une des préoccupations des organismes en charge de la radioprotection. Le flux de particules cosmiques est significativement plus élevé à bord des avions qu'au niveau du sol. De plus, son intensité dépend de l'activité solaire et des éruptions. De par leur activité professionnelle, les équipages et les voyageurs fréquents peuvent recevoir une dose annuelle de plusieurs millisieverts. C'est pourquoi la directive européenne adoptée en 1996 demande aux compagnies aériennes d'estimer la dose et d'informer les personnels navigants sur le risque. La dose efficace doit être estimée en utilisant divers moyens expérimentaux ou par calcul. En France, le système d'information et d'évaluation par vol de l'exposition au rayonnement cosmique dans les transports aériens (SIEVERT) est proposé aux compagnies pour les assister dans l'application de la directive européenne. Ce système a été développé par la Direction générale de l'aviation civile (DGAC) et ses partenaires : l'Institut de radioprotection et de sûreté nucléaire (IRSN), l'Observatoire de Paris et l'Institut français pour la recherche polaire - Paul-Émile Victor (PEV). Ce service professionnel est disponible sur un

\footnotetext{
IRSN, B.P. 17, 92262 Fontenay-aux-Roses, France.

2 Air France, B.P. 10201, 95703 Roissy-Charles de Gaulle, France

3 Direction générale de l'aviation civile, 50 rue Henry-Farman, 75020 Paris. France.

4 Observatoire de Paris, 92195 Meudon, France.
} 
serveur Internet pour les compagnies avec une section pour le public. Ce système fournit les doses en considérant les routes empruntées par les avions. Différents résultats obtenus sont présentés.

\section{Introduction}

The study of naturally-occurring radiation and its effects on man is one of the preoccupations of organisations responsible for radiation protection.

Cosmic particle flux increases with latitude and altitude and is significantly higher on board aircraft than at ground level. The complexity of the radiation field does not make dose measurement easy. Indeed, the particles encountered vary considerably and a wide range of energies and types of particle are found. The gravity of the consequences for biological structures depends on the energy. Therefore, if the effective dose is to be estimated, the absorbed dose has to be known, along with the radiation weighting factor.

Recently, the International Commission on Radiological Protection (ICRP) included for the first time exposure to enhanced or elevated levels of radiation from natural sources in its radiation protection recommendations (ICRP, 1991). Following these recommendations, the European Commission (EU) introduced a revised Basic Safety Standards Directive (European Commission, 1996) which includes the exposure of aircraft crew to cosmic radiation as occupational exposure.

In France, the Computerized System for Flight Assessment of Exposure to Cosmic Radiation in Air Transport, or "SIEVERT", is delivered to airlines for assisting them in the application of article 42 of the European Directive. This dose assessment tool was developed by the French General Directorate of Civil Aviation (DGAC) and partners: the Institute for Radiation Protection and Nuclear Safety (IRSN), the Paris Observatory and the French Institute for Polar Research - Paul-Émile Victor (IPEV). This professional service is available on an Internet server accessible only to companies that applied for it to DGAC. However, a public section enables passengers to assess the dose received during a flight. This server is operated by IRSN.

SIEVERT is a tool suited for flight crew dosimetry for cosmic radiation. It requires no specific skill with regard to radiation protection within the airline. It generates no operating requirements for the personnel, as this is the case for personal dosemeters.

SIEVERT should provide a correct application of the regulation for at least three reasons. First, the results obtained are close enough to reality to avoid 
under-estimating the doses received by the personnel. Second, the radiation dose assessment mode is the same for all airlines. Third, if checks become required in the future, retrospective dose calculations might always be performed.

\section{Exposure to cosmic radiation in aircraft}

The radiation dose resulting from cosmic radiation received aboard aircraft is greater than that received at ground level. Due to their professional activities, flight personnel can receive an effective dose of several $\mathrm{mSv}$ in a year

\subsection{Exposure increases with altitude}

As we gain altitude, the protective atmospheric layer grows thinner, increasing our exposure to cosmic radiation. At the cruising altitude of commercial aircraft, i.e. from 10000 to 12000 meters, cosmic radiation is approximately 100 to 300 times more intense than at sea level. Aboard the Concorde, which flies at 18000 metres, the dose rate is almost twice higher than on subsonic planes.

\subsection{Exposure varies according to latitude}

Particles of cosmic radiation penetrate more easily at high latitudes, near the poles, than in the vicinity of the equator because of the barrier provided by the earth's magnetic field. Depending on the latitudes of the plane's route, we are therefore more or less exposed to radiation.

Measurements taken aboard aircraft during the 1990s (Fig. 1) showed that flight personnel on long-haul flights receive an effective dose of between 2 to $5 \mathrm{mSv}$ per year depending on the routes used by the aircraft and on solar activity (Bottollier-Depois et al., 2000).

\section{The SIEVERT system}

The SIEVERT system was designed to be an operational tool dedicated to legal dosimetry of aircrews and uses, to create dosimetric inputs, already existing codes like CARI (O’Brien et al., 1996) during normal solar activity. This system provides doses that consider the routes flown by aircraft. These values are calculated using models verified over several tens of flights with a satisfactory uncertainty margin. Also, in case of solar flare, a model was developed and allows assessing the impact with regard to the dose received (Lantos and Fuller, 2003; Lantos et al., 2001). 


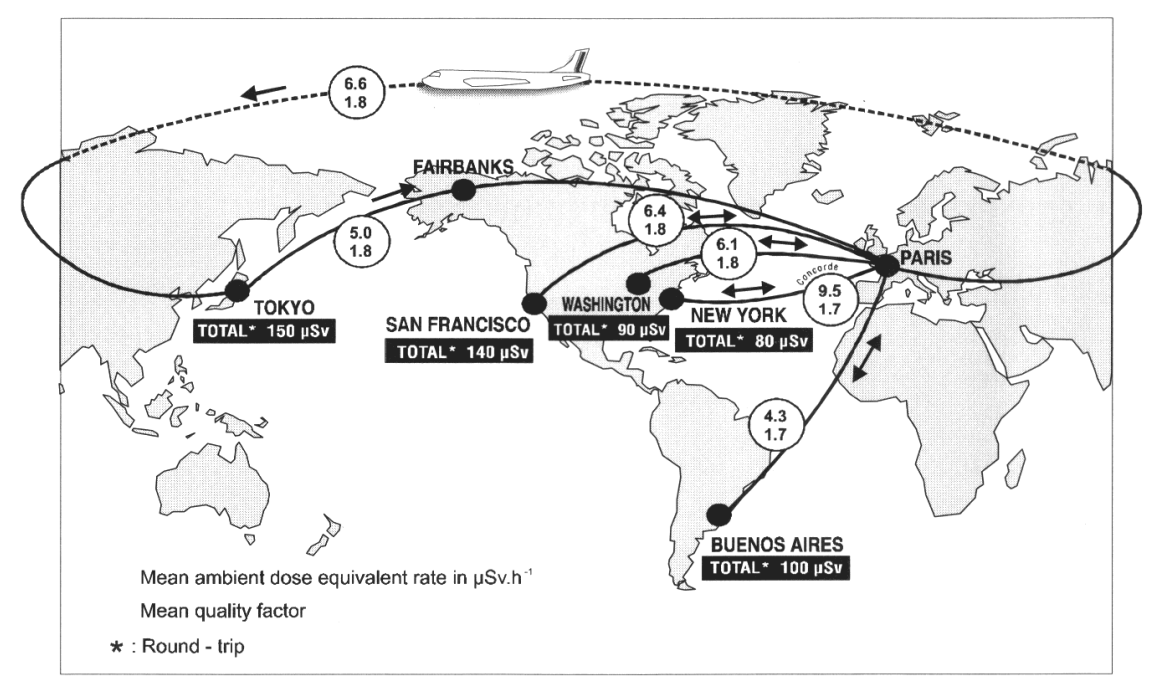

Figure 1 - Doses received during different flights obtained from measurements taken between 1996 and 1998 using NAUSICAA equipment. The circles contain the average dose equivalent rate on the flight in $\mu \mathrm{Sv} / \mathrm{h}$, and the radiation mean quality factor (dose equivalent to absorbed dose ratio). The total dose equivalent (mean rate $x$ time) is given for a round-trip flight.

Doses reçues lors de différents vols obtenues à partir de mesures réalisées entre 1996 et 1998 avec l'appareil NAUSICAA. Dans les cercles sont mentionnés le débit d'équivalent de dose moyen sur le vol $(\mu \mathrm{Sv} / \mathrm{h})$ et le facteur de qualité moyen du rayonnement (rapport de l'équivalent de dose sur la dose absorbée). L'équivalent de dose total (débit moyen $\times$ temps) est donné pour un vol aller-retour.

\subsection{The SIEVERT principle}

Airspace, at the heart of SIEVERT, is divided into cells. Each cell has an altitude of 1000 feet, $10^{\circ}$ in longitude and $2^{\circ}$ in latitude. Altogether they form a map of 265000 cells; to each of these cells is assigned an effective dose rate value. The time spent by the plane on each cell and the corresponding dose are calculated (Fig. 2); their accumulative total gives the dose received during the flight.

\subsection{Updating the dosimetric data}

The IRSN updates the map of the dose rates every month by taking solar activity into account (Fig. 3). This map is obtained using a computer code (currently CARI 6 (O'Brien et al., 1996), developed by the Federal Aviation Administration) which allows the dose to be obtained at any point in space up to an altitude of 80000 feet. Regular radiation measurements, from dosemeters installed on the 


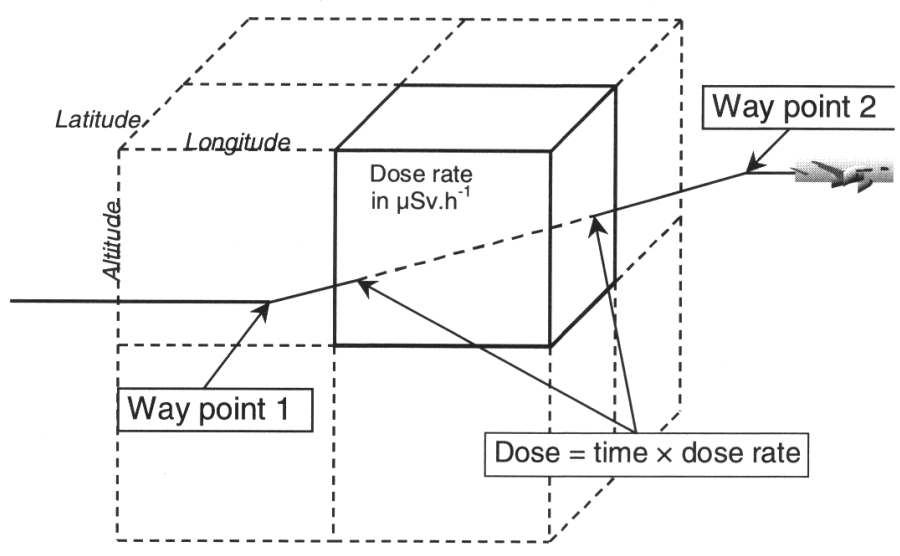

Figure 2 - Principles for calculating the dose during a flight with SIEVERT.

Principe de calcul de la dose pour un vol dans SIEVERT.

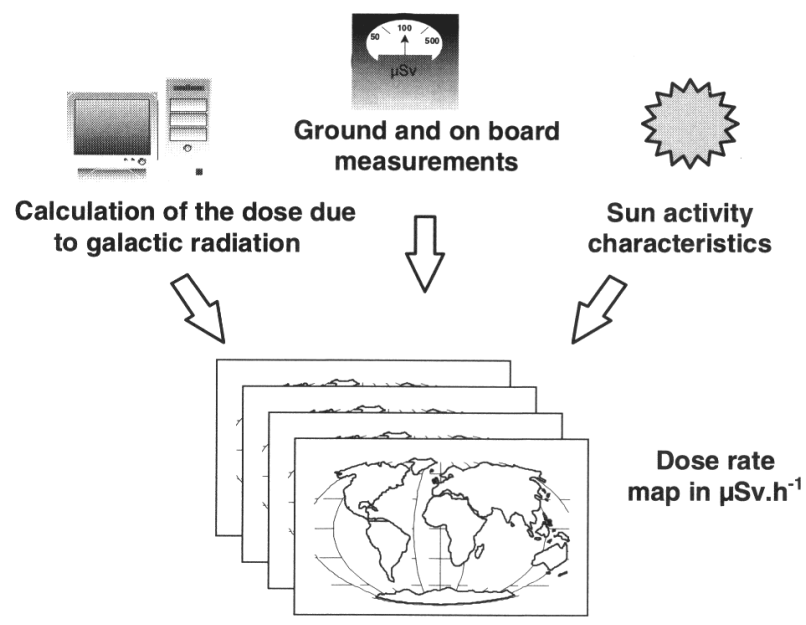

Figure 3 - The various input data required for SIEVERT to operate.

Les différentes données d'entrée nécessaires au fonctionnement de SIEVERT.

ground and on aircraft, are then used to confirm and, if necessary, to correct the obtained values. In the event of a significant solar flare, a specific map is created and validated. Astrophysicists at the Paris observatory are also asked to assess the impact of the solar flare. The time needed to carry out this complex study is rather long. It is therefore necessary to wait several weeks before being able to calculate the doses received on flights during a solar flare. 


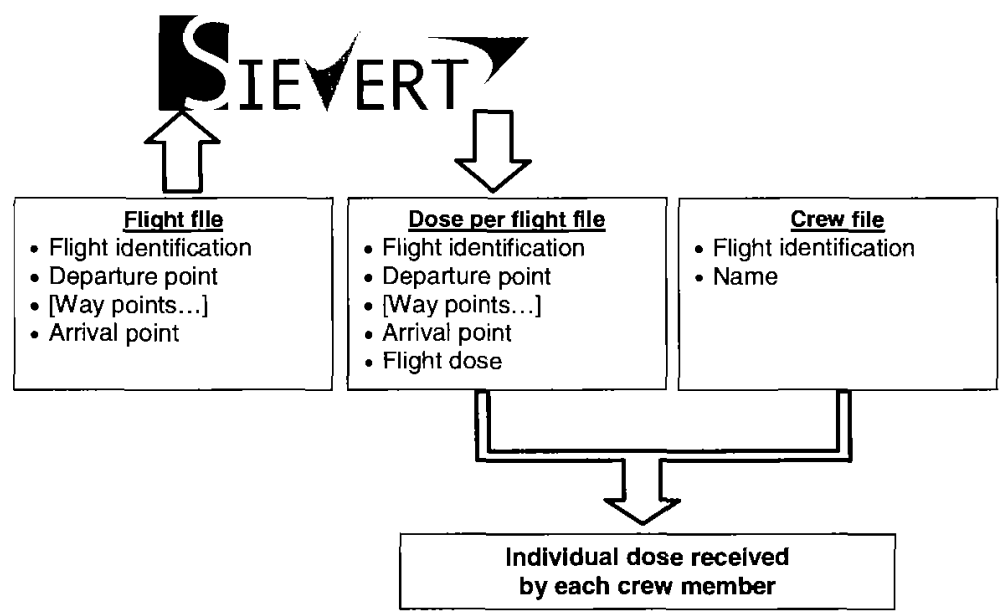

Figure 4 - Principles of data exchange between SIEVERT and the airline companies.

Principe d'échange des données entre SIEVERT et les compagnies aériennes.

\subsection{Principles in using SIEVERT}

The company prepares a file of completed or scheduled flights, and sends it to the SIEVERT Internet address. The system then completes the file by adding the effective dose that corresponds to each flight (Fig. 4). Doses are calculated according to flight characteristics, using the dosimetric input data validated by the IRSN. The more detailed is the information concerning the route, the greater is the accuracy of the dose value. If the information is minimal, the dose value is assessed using a standard route profile (Fig. 5). The data, at this stage, are anonymous. It is then necessary to add up the doses received during flights carried out by each member of the flight personnel. This information is made available to the person in question, and is communicated to the occupational medical service and to the national register.

It is also possible for the general public to assess the dose received during one or more flights by accessing the SIEVERT Internet site ( $w w w /$ sievert-system.com, Fig. 6). This assessment is carried out using information contained on the flight ticket. Furthermore, general information about the cosmic rays, the regulation and the risk associated to radiation is available on this site.

\section{Validation and initial results}

During the regular scheduled run verification stage (VSR), which precedes commissioning, full scale calculations were carried out by the IRSN (Dosimetry 


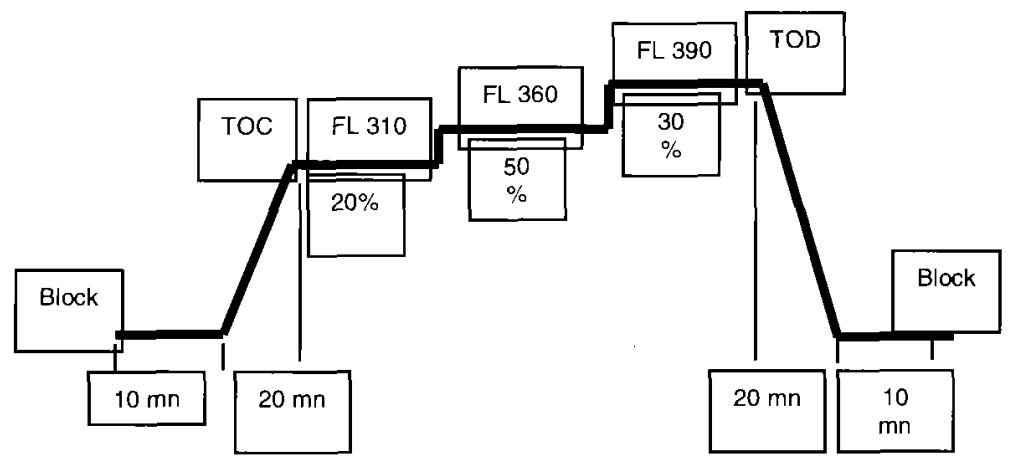

Figure 5 - Criteria used for the definition of a standard flight profile for long-haul subsonic flight. TOC: top of climb, TOD: top of descent, FL: flight level (ft/I00), block: parking.

Critères utilisés pour définir un profil de vol standard pour un vol long-courrier subsonique. TOC : fin de montée, TOD : début de descente, FL : niveau de vol (ft/lO0), block: parking.

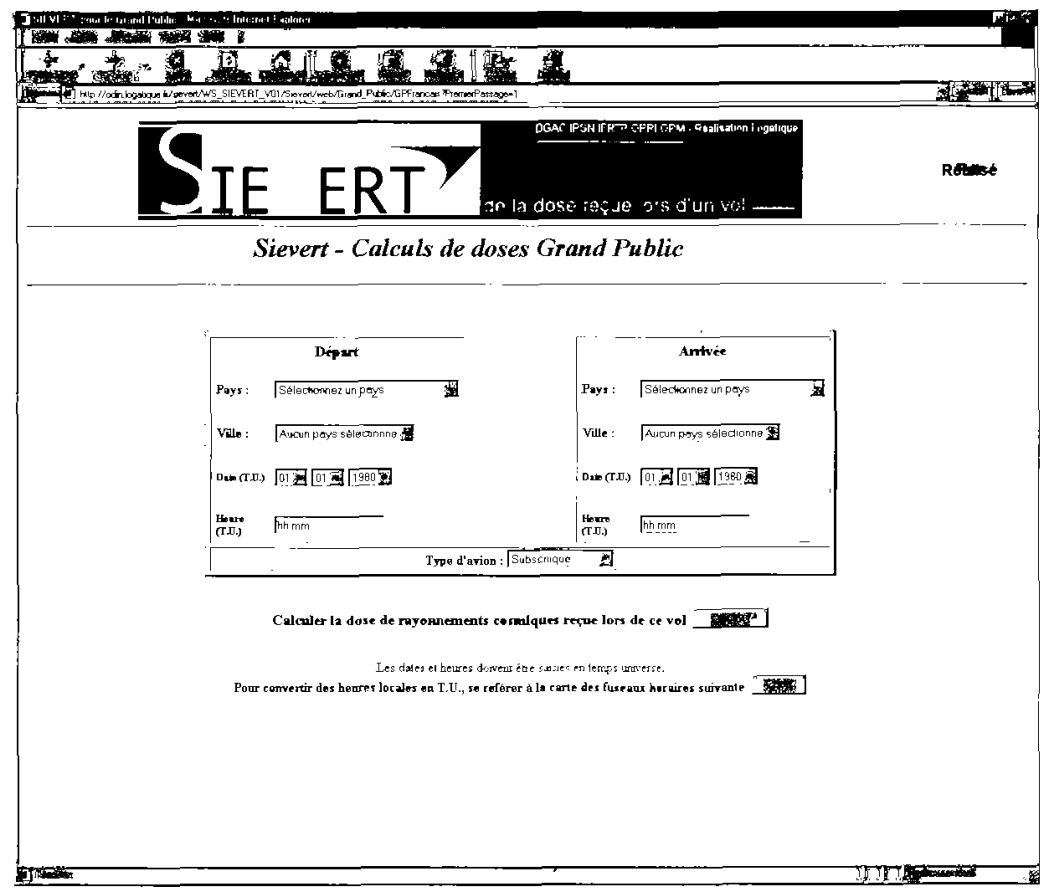

Figure 6-Input data window for public dose assessment using data available on the flight ticket (departure and arrival location, date and time of flight, aircraft type).

Fenêtre de saisie des données pour l'estimation de dose du public en utilisant les données disponibles sur le billet de vol (lieu de départ et d'arrivée, date et heure du vol, type d'avion). 


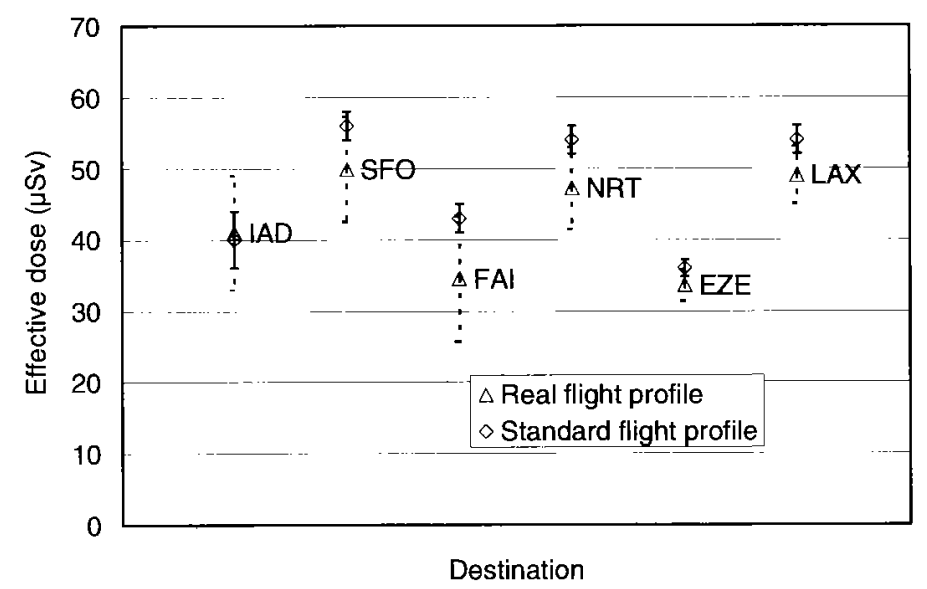

Figure 7 - Comparison of doses obtained with a combination of flights both actual and standard for various routes with a Paris departure over a time period of one month (IAD: Washington, SFO: San Francisco, FAI: Fairbanks, NRT: Tokyo, EZE: Buenos Aires, LAX: Los Angeles).

Comparaison des doses obtenues avec un ensemble de vols réels et standard pour différentes routes au départ de Paris sur une période d'un mois (IAD: Washington, SFO: San Francisco, FAI : Fairbanks, NRT : Tokyo, EZE : Buenos Aires, LAX : Los Angeles).

department), in particular with Air France. Tens of thousands of flights were processed.

\subsection{Standard flight profile validation}

A statistical study of these initial results allowed us to validate a certain number of parameters, in particular those used to define a standard flight profile which is used for the general public when the actual profile is unknown. These initial results show, amongst other things, that the dose dispersion for a given destination can be significant (up to factor 1.7 ) as the length of a flight can vary according to environmental parameters such as meteorological conditions. The values obtained with the standard profile are usually in the upper section of the dose range for a given route; this is so that a conservative approach is maintained (Fig. 7).

\subsection{Model validation in the event of a solar flare}

Dose measurements throughout a flight during which a solar flare, detectable from the ground, took place were carried out for the first time on the 15th April 2001 on a Prague-New York flight (Fig. 8). These measurements were obtained by Spurny (Spurny and Datchev, 2001) whilst working on an European contract which united 


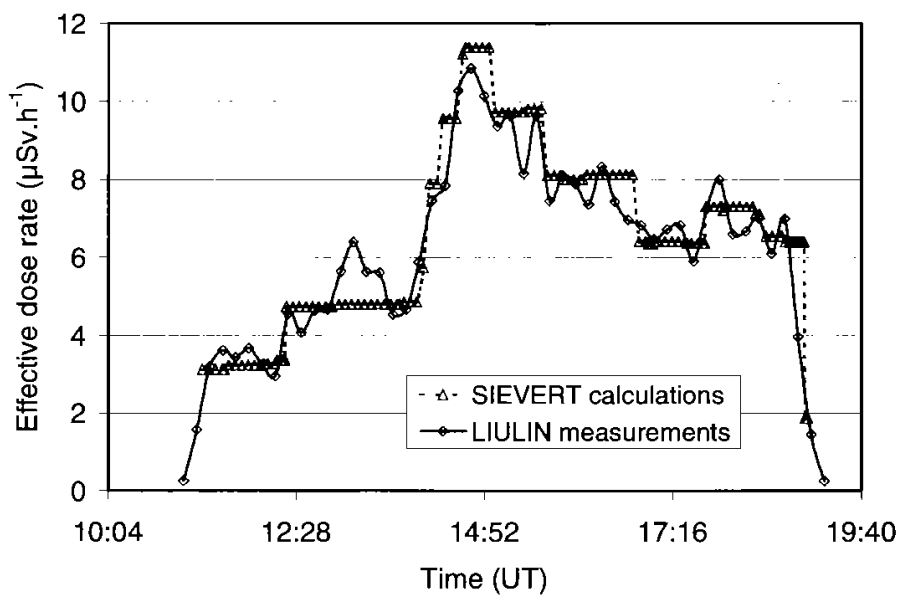

Figure 8 - Profile of the dose rate measured using the "LIULIN" detector (semiconductor detector) and calculated by SIEVERT for a Prague-New York flight on the I5th April 200I during the GLE 60 which occurred at 14 h09 UTC.

Profil du débit de dose mesuré à l'aide du détecteur LIULIN et calculé par SIEVERT pour un vol Prague-New York le 15 avril 2001 lors du GLE 60 qui a débuté à 14h09 TU.

7 institutes including IRSN. Such events, known as Ground Level Events (GLE), happen, at most, several times a year. The dosimetric model set up in SIEVERT in the event of a solar flare could, therefore, be validated. This model is based on the attenuation in the atmosphere of particles with an energy comparable to that of the solar flares and on the data from the neutron monitors located on the ground which provide the intensity of the GLE.

\section{Conclusion}

SIEVERT, of an operational nature, is the answer to a request from the airline companies for radiation protection for flight personnel. Moreover, it makes it possible to assess the dose received during a flight for anybody who wants it.

A pioneering aspect of SIEVERT lies in the fact that a regulatory dosimetry is carried out solely using a calculation based on models which have, of course, been validated through experience.

SIEVERT is the first system able to reply fully to all operational constraints for aircrew regulatory dosimetry, whether they are those of the aeronautical industry operators or those linked to regulatory dosimetry. Foreign companies have already shown an interest in the use of such a system. 


\section{REFERENCES}

Bottollier-Depois J.F., Chau Q., Bouisset P., Kerlau G., Plawinski L., Lebaron-Jacobs L. (2000) Assessing exposure to cosmic radiation during long-haul flights, Radiat. Res. 153, 526-532.

European Commission (1996) Official publication of the European Communities, L 159.

ICRP Publication 60 (1991) Recommendations of the International Commission on Radiological Protection, Ann. ICRP 21(l-3).

Lantos P., Fuller N. (2003) History of the solar flare radiation doses on-board aeroplanes using semiempirical model and Concorde measurements, Radiat. Prot. Dosim., to be published.

Lantos P., Fuller N., Bottollier-Depois J.F. (2001) Monitoring the radiation doses received by airs crews, Proceedings of ICRC 2001, pp. 4067-4070.

O'Brien K., Friedberg W., Sauer H.H., Smart D.F. (1996) Atmospheric Cosmic Rays and Solar Energetic Particules at Aircraft Altitudes, Environ. Int. 22(Suppl. 1), 9-44.

Spurny, F., Datchev T. (2001) Measurement in an aircraft during an intense solar flare, Ground Level Event 60, on the 15th April 2001, Radiat. Prot. Dosim. 95, 273-275. 